\title{
The nesting behaviour of the mason bee Osmia cornuta (Latr) with special reference to its pollinating potential (Hymenoptera, Megachilidae)
}

\author{
J Bosch \\ Dept Biologia Animal, Fac Biologia, Univ Barcelona, Diagonal, 645, 08028 Barcelona, Spain
}

(Received 5 October 1992; accepted 30 July 1993)

\begin{abstract}
Summary - The nesting behaviour of Osmia cornuta was studied in managed populations released in almond orchards. A correlation between the dry weight of a provision and the number of pollen grains in the provision was established. Male and female provisions contain a mean of 4634304 and 8046425 almond pollen grains, respectively. A correlation between the dry weight of a provision and the number of foraging trips was also established. The mean number of foraging trips necessary to complete a provision was 16.76 for male provisions and 26.79 for female provisions. During an almond blooming period, each $O$ cornuta female potentially visits from 9500 to 23600 almond flowers. Given the pollinating efficiency of $O$ cornuta on almond, 3 females per tree are considered sufficient to maximize pollination in an almond orchard.
\end{abstract}

Osmia cornuta / nesting behaviour / pollination / Prunus amygdalus

\section{INTRODUCTION}

Because of its pollen-collecting preferences (Rosaceae (Taséi, 1973b; Asensio, 1984; Marquez et al, 1994)) and its flying period (February-April) in synchrony with bloom of fruit trees, Osmia cornuta has been studied as a potential pollinator in almond and apple orchards (Asensio, 1984; Torchio and Asensio, 1985; Torchio et al, 1987; Krunic et al, 1989, 1991; Bosch, 1994a, 1994c). These studies have shown that, through adequate management practices, populations of this pol- linator can be increased in orchard environments, and that $O$ cornuta is a very efficient pollinator of almond flowers (Bosch and Blas, 1994).

A necessary following step in the development of $O$ cornuta as an orchard pollinator is the estimation of the number of bees necessary per unit area of crop. The population introduced in a given orchard should be large enough to ensure adequate levels of pollination, and low enough so that it can be supported by the available pollen-nectar sources. The supersaturation of an orchard with Osmia bees 
is likely to cause an increase in the dispersal of prenesting females (Bosch, 1994b) and/or a decrease in size and nectar concentration of the pollen-nectar provisions constructed, with a subsequent increase in immature mortality (Torchio, 1985).

The number of individuals needed per unit area will vary from orchard to orchard according to numerous parameters, such as weather, size of trees, attractiveness of cultivars, number and distribution of pollenizers, populations of other pollinating insects, etc. While it is not possible to measure all these parameters for each orchard, it is possible to make general estimates that apply to most places and years. Several approaches have been used to estimate concentrations of Osmia pollinators needed per unit area of orchard. Some of these approaches (direct approaches) are based on the measure of fruit-set, in plants visited by different numbers of pollinators. This can be accomplished by caging plants (Torchio, 1979), or by using different concentrations of pollinators in different places (Yamada et al, 1971) or years (Torchio, 1985). Other methods (indirect) are based on the estimation of the number of flowers to be pollinated, the number of visits necessary to pollinate a flower, and the number of visits made per individual pollinator (Yamada et al, 1971; Maeta and Kitamura, 1974, 1981).

In this study, the time spent in each nesting task of $O$ cornuta, and the number of trips necessary to provision cells, and construct cell partitions and nest plugs were measured. The number of pollen grains per provision was also estimated. These data combined with results obtained on cell production, flower-visiting rates, and pollinating efficiency of $O$ cornuta (Bosch and Blas, 1994) have provided a framework to accurately measure population densities of $O$ cornuta required to maximize pollination of almond.

\section{Life cycle of Osmia cornuta}

$O$ cornuta is a solitary bee that nests in preexisting cavities, in which it builds linear series of cells separated by mud partitions. Each cell is provisioned with a pollennectar loaf on top of which an egg is deposited. At the end of each series of cells the female builds a thick terminal mud plug that seals the nest. One female may build as many as 7 nests (unpublished data).

Like many other aculeate cavity nesters (Krombein, 1967), O cornuta females usually lay their female eggs in the first (innermost) cells of the nest, and male eggs in the last-built cells (outermost cells). Female provisions are typically larger than male provisions, and female bees are typically larger than males.

Eggs hatch a few days after they have been laid (February-March), and larvae feed on the pollen-nectar provision until this is completely consumed (May-June). Then, fifth instar defecated larvae spin their cocoons, but pupation does not occur until August-September. At this time, bees reach the adult stage and remain in diapause inside their cocoons for the winter. A period of low temperature is necessary to break diapause (Taséi, 1973a), and adults reactivate in February-March when temperatures rise.

Male emergence starts a few days before female emergence. After mating, females initiate nesting activities; that is, they select a hole in which to nest, collect pollen and nectar to provision it, lay eggs, and collect moist soil to build cell partitions and terminal nest plugs.

\section{MATERIALS AND METHODS}

Field observations were carried out in 1991 at 3 nesting shelters; 1 located in an experimental almond orchard at the Agricultural Research Sta- 
tion of Mas Bové (IRTA), and the other 2 in commercial almond orchards in Parc de Samà and Vila-Seca (Tarragona, NE Spain). Laboratory work was undertaken at the Department of Animal Biology (Univ of Barcelona) facilities.

\section{Provisions and mud structures}

Nests recently built in paraffinated paper straws $8 \mathrm{~mm}$ inside diameter and $15 \mathrm{~cm}$ long by females of a managed population released in an almond orchard in Parc de Samà (Baix Camp, NE Spain) in 1990 were dissected. Eggs were removed, and pollen provisions were carefully placed in pre-weighed individual aluminium paper envelopes and assigned male or female condition according to their size and position within the straw. Mud partitions and terminal plugs were also carefully removed and wrapped in pre-weighed pieces of aluminium paper. Envelopes with mud partitions were dried in a stove at $60^{\circ} \mathrm{C}$, and envelopes with pollen-nectar provisions were dehydrated in a lyophilizer. All samples were then weighed on a precision balance.

To establish a correlation between pollen weight and number of pollen grains, small pieces of dehydrated provisions were cut and weighed on a precision balance. These pieces were then introduced into glass vials with $10 \mathrm{ml}$ distilled water and some detergent to facilitate separation of pollen grains. The liquid was stirred until the pollen provision portion had completely disintegrated. The vial was placed in a vortex mixer, to allow for even suspension of pollen grains throughout the liquid, and $105-\mu$ l samples of the suspension were taken with a micropipette and individually deposited on a glass slide. Pollen grains in each droplet were counted under the microscope, and the mean number of pollen grains counted was multiplied by 2000 to obtain an estimation of the number of pollen grains in each piece of provision.

\section{Cocoons}

Other nests in $8 \mathrm{~mm} \times 15 \mathrm{~cm}$ and $7 \mathrm{~mm} \times 15 \mathrm{~cm}$ straws from the same population were left undisturbed until October, at which time nests were dissected, cocoons were separated, and all fecal particles were removed. Each cocoon was sexed by cutting a small slit below the nipple and observing the facial pilosity of the bee. The pilosity of males is more abundant and white, whereas that of females is scant and black. The sexed cocoons were then placed in winter refrigerators.

\section{Foraging and nesting activity}

To determine the temperature threshold for $O$ cornuta foraging activity, nesting shelters were observed in the early morning, and when all or most of the nesting females had left their holes and started foraging activities; air temperature was recorded at a neighbouring weather station. In the late afternoon, when most females had returned and remained inside their nests, air temperature was again recorded.

Some holes in which nesting activities were under way were continuously observed, and the time spent by nesting females inside and outside the nest was measured. This was done for females collecting pollen and nectar, and for females collecting mud.

\section{Mud loads}

To determine the quantity of mud that a bee transports to the nest on each mud-collecting trip, holes in which partitions or plugs were being built were observed until the nesting female came back with a mud load. When the bee was about to enter the hole, it was gently pressed with a finger against the nesting material, which caused it to release the mud load and fly away. Mud loads obtained in this way were collected, dried at $60^{\circ} \mathrm{C}$ and weighed.

\section{Pollen loads}

To estimate the quantity of pollen transported by a bee on each foraging trip, holes in which a bee was about to provision a new cell were selected. These holes were continuously observed and the number of times a bee entered them with pollen loads on the scopa were recorded. At the end of the day the straws containing these half-provisioned cells were removed from 
the nesting material and taken to the laboratory. The straws were then dissected and the partial provisions were carefully removed and placed in pre-weighed aluminium envelopes. These samples were dehydrated and weighed as described above. In this way, an estimation of the dry weight of a pollen load was obtained.

\section{RESULTS AND DISCUSSION}

\section{Nesting behaviour}

Nesting $O$ cornuta females initiated foraging activity in the morning when the air temperature approached $12^{\circ} \mathrm{C}$ (mean: 12.19; SD: $0.55 ; n=11$ ). The temperature at which bees suspended foraging activity in the afternoon or evening ranged from 13 to $16^{\circ} \mathrm{C}$, and it increased from the beginning to the end of the nesting season.

$O$ cornuta females collect nectar and pollen in tandem when they visit almond flowers (Bosch and Blas, 1994). Nectar is carried in the crop, and pollen on the ventral scopa of the abdomen. When the bee returns to its nest, it enters head first and regurgitates the nectar load. It then crawls out of the hole, where it turns and reenters the nest backwards. The bee then crawls back to the bottom of the nest and brushes its abdomen with its hind legs so that the pollen load is deposited on the provision initiated. After several of these trips, the provision is completed and the female lays the egg on the surface of the provision.

Upon egg deposition, the bee exits the hole and flies away, to return some time later with a glob of mud held under the head and behind the mandibles. This nesting material is collected with the mandibles at crevices and holes in the ground, where soil is moist but not super-saturated. Many females have been observed to collect moist soil at the same source, adjacent to one another. Mud loads are deposited in the nest and moulded with the mandibles until a concave partition covering the hole diameter of the nesting hole is formed.

Following the sequence described above, a series of cells are provisioned and sealed. At the end of each series, females may optionally build 1 (rarely 2) vestibular cells (empty cells), and the nest entrance is then sealed with a thick mud plug.

The times spent on each nesting activity are included in table I. Thus, mud collecting trips are shorter than foraging trips, but mud deposition takes about as long as nectar-pollen deposition. These data are similar to those reported for Japanese Osmia species, which spend at least 6-8 min on each pollen-nectar foraging trip in apple orchards, and 1-5 minutes on each of the other nesting activities (Maeta, 1978). Similarly, Osmia lignaria propinqua spend about 1 min per mud collecting trip, and 14 min per foraging trip in the field (Levin, 1966). The time spent by this species depositing mud and pollen-nectar loads is about $1.5 \mathrm{~min}$ (Levin, 1966).

O cornuta females also spend variable amounts of time searching for and inspecting holes in which to nest, cleaning holes, expelling intruders from their nest, etc.

Mean weights of mud partitions, terminal plugs and mud loads carried by the

Table I. Times (in min) spent by $O$ cornuta females at different nesting activities.

\begin{tabular}{lrrr}
\hline & $n$ & Mean & $\begin{array}{c}\text { Standard } \\
\text { deviation }\end{array}$ \\
& & & \\
\hline Mud collecting trip & 141 & 2.72 & 3.04 \\
Mud deposition & 137 & 1.87 & 1.76 \\
Foraging trip & 82 & 11.48 & 9.82 \\
Nectar + pollen & & & \\
deposition & 97 & 2.28 & 1.90 \\
Egg laying & 8 & 4.11 & 5.76 \\
\hline
\end{tabular}


Table II. Dry weights (in g) and number of mud loads necessary to build different mud structures of $O$ cornuta nests.

\begin{tabular}{lcccc}
\hline & $\mathrm{n}$ & Mean & Standard deviation & No of mud loads \\
& & & & \\
\hline Initial partition & 28 & 0.18 & 0.06 & 6.88 \\
Intercell partition & 50 & 0.11 & 0.03 & 4.41 \\
Vestibular partition & 49 & 0.30 & 0.16 & 11.88 \\
Terminal plug & 48 & 0.54 & 0.15 & 21.09 \\
Mud load & 19 & 0.03 & 0.01 & - \\
\hline
\end{tabular}

bees are indicated in table II. Intercell partitions are the lightest, followed by initial partitions, vestibular partitions, and nest plugs. By dividing the weights of these different mud structures by the mean weight of a mud load, the number of mud collecting trips necessary to build each structure is obtained (table II). The number of loads used to build an intercell partition is lower (4.4) than in $O$ lignaria propinqua (8-12) (Torchio, 1989).

\section{Theoretical sex ratio}

The distribution of dry weights of male and female provisions overlapped, but the mean weight of the latter $(0.451 \pm 0.069 \mathrm{~g}$, $n=61)$ was significantly higher than that of the former $(0.260 \pm 0.034 \mathrm{~g}, n=58)(t-$ Student $=19.05, p<0.0001)$.

According to Fisher's (1930) theory, parental investment should be equally distributed among progeny of both sexes, and therefore, it is expected that fewer members of the sex with highest production costs will be produced. Weights of pollennectar provisions made by bees are easy to measure and can be considered an index of the energy invested by parent females in their progeny. For these reasons, Fisher's theory has been applied to a number of species of solitary bees to obtain their expected (optimal) sex ratio (eg, Tor- chio and Tepedino, 1980). The expected sex ratio of $O$ cornuta calculated from its provision weights is 1.74 males: 1 female, which is slightly higher than sex ratios obtained in wild populations (1.1-1.5 males: 1 female) (unpublished data).

Female cocoons recovered from the $8 \mathrm{~mm}$ straws weighed $0.235 \pm 0.032 \mathrm{~g}(n=$ $50)$, and male cocoons weighed significantly less $0.142 \pm 0.024 \mathrm{~g}(n=50)(t-$ Student $=16.55, p<0.0001)$. Female cocoons from the $7 \mathrm{~mm}$ straws weighed $0.202 \pm 0.021 \mathrm{~g}(n=50)$, and male cocoons weighed $0.129 \pm 0.022 \mathrm{~g}(n=50)(t$ - Student $=17.03, p<0.0001)$. Differences in weight between female cocoons from either 8 or $7 \mathrm{~mm}$ straws and between male cocoons from both types of straws were statistically significant $(t-$ Student $=6.10$, $p<0.0001$; and $t-$ Student $=2.74, p<$ 0.01 , respectively). The theoretical sex ratio calculated from cocoon weights was similar to the theoretical sex ratio calculated from provision weights: 1.66 males per female form the $8 \mathrm{~mm}$ straws, and 1.57 males per female for the $7 \mathrm{~mm}$ straws.

\section{Number of pollen grains per provision}

All samples used to establish a correlation between pollen weight and number of pollen grains contained more than $90 \%$ almond pollen by number. Correlation be- 


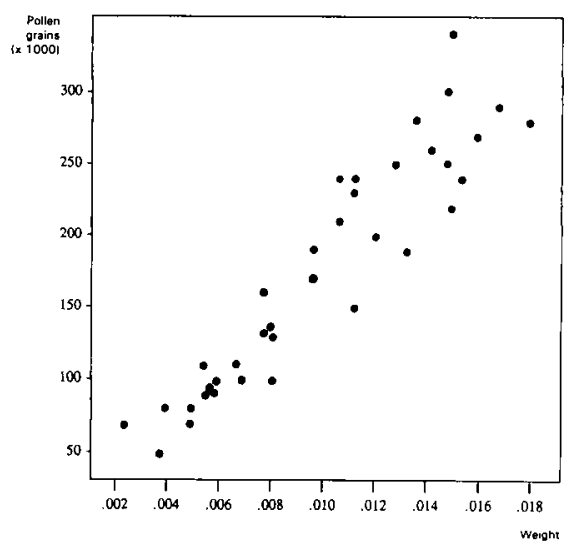

Fig 1. Correlation between number of pollen grains and dry weight (in g) of pollen mass. Regression equation: $y=17858298 x-3188(r=$ $0,936, p<0.00001$ ).

tween these 2 parameters was significant $(N=37, r=0.936, p<0.00001)$ (fig 1) with the regression equation:

No pollen grains $=17858298 *$ weight 3188

Thus, male provisions in the $8 \mathrm{~mm} \times 15$ $\mathrm{cm}$ straws contain $4634304 \pm 598283$ pollen grains (range: $3516682-$ 6213285 ), and female provisions contain $8046425 \pm 1232940$ pollen grains (range: 5322 156-10 961807 ). Maeta (1978) estimated about 7000000 apple pollen grains per provision in Osmia cornifrons and about 9000000 in Osmia taurus.

\section{Number of flowers visited per provision}

A significant correlation was found between the number of foraging trips and the weight of pollen-nectar provision ( $n=34$, $r=0.853, p<0.00001$ ) (fig 2) with the regression equation:

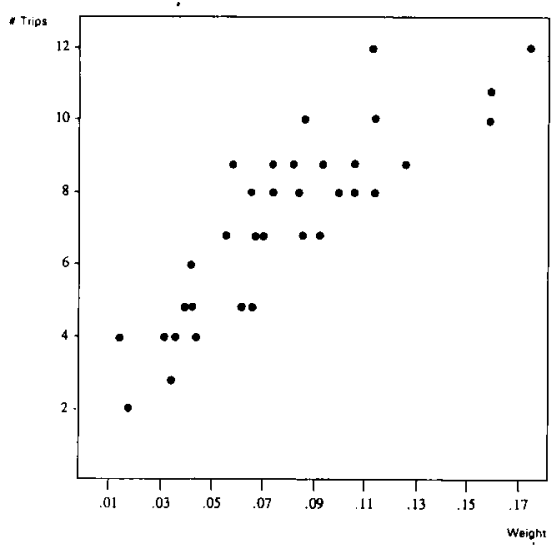

Fig 2. Correlation between number of foraging trips and dry weight (in g) of pollen mass. Regression equation: $y=52.49899 x+3.12747$ $(r=0.853, p<0.00001)$.

No trips $=52.49899$ * weight +3.12747

When the average weights of male and female provisions were added to the equation, we found that 13.48 to 21.40 foraging trips (mean: 16.76, SD: 1.76) are necessary to complete a male provision, and 18.78 to 35.36 (mean: 26.79 , SD: 3.62 ) are needed to complete a female provision. Maeta (1978) reported that a provision of $O$ cornifrons requires 11-35 pollen loads, and a provision of $O$ taurus 12-37 loads. Similarly, $14-35$ foraging trips are necessary. to provision a cell in O lignaria (Torchio, 1989).

As indicated in table $\mathrm{I}$, foraging trips average $11.48 \mathrm{~min}$. Some of the time is spent flying from the nest to the first tree visited, grooming, and flying back to the nest. If we presume that these activities consume a third of the time the bee spends outside its nest, bees visit flowers for 7.65 min per foraging trip. Visitation rates of 770 cornuta females averaged 7.9 visits per min (Bosch and Blas, 1994), which translates to 60 flowers visited per foraging trip. 
Therefore, 1000 flower visits are made to produce a male provision and 1600 visits to produce a female provision. Maeta and Kitamura (1974) assumed that all time spent by $O$ cornifrons on a foraging trip was devoted to visiting flowers, and they, therefore, concluded that this species visited as many as 90 flowers per foraging trip. As a consequence, they estimated that an average $O$ cornifrons provision required 1620 flower visits.

\section{Pollinating potential of $\mathrm{O}$ cornuta on almond}

In earlier studies with marked and unmarked bees released in almond orchards, the number of male and female cells produced per $O$ cornuta nesting female was determined (Bosch, 1992). In some of these releases, the time available for nesting activities was considerably reduced for a variety of reasons. Under these circumstances each $O$ cornuta female constructed 2.5 female cells and 5.5 male cells on average (Bosch, 1994a, 1994c, and unpublished data). Under more favourable conditions (extended blooming periods and good weather) cell production was as high as 6 female cells and 14 male cells per nesting female (Bosch, 1994c). These figures are similar to cell production data reported for other Osmia pollinators: $O$ lignaria propinqua foraging in an apple orchard produced 7.97 cells per female released when pollen-nectar resources were too low to adequately support the entire population, and 17.59 cells per female released when these resources were abundant (Torchio, 1985); when pollen-nectar resources in apple orchards were moderately abundant, $O$ cornifrons provisioned 4 female and 6 male cells, and when they were abundant, these numbers increased to 5 and 7 , respectively (Maeta and Kitamura, 1974; Maeta, 1978). The maximum egg-laying potential in $O$ cornifrons, $O$ lignaria and $O$ cornuta seems to be around 30 eggs (Maeta and Kitamura, 1974; Maeta, 1978; Phillips and Klostermeyer, 1978; Torchio et al, 1987; Torchio, 1989). These data suggest that an $O$ cornuta female can visit from 9500 to 23600 flowers while nesting in almond orchards.

O cornuta females contact the stigma of almond flowers in $98.71 \%$ of their visits, and single visits of this pollinator to otherwise unpollinated flowers of the cultivar Ferragnes yielded fruit sets of 21.84 and $38.10 \%$ in 1989 and 1991, respectively (Bosch and Blas, 1994). Hand-pollination experiments on Ferragnes in 3 different orchards in 1900 and 1992 yielded fruit-sets of $8.92,25.49$ and $38.29 \%$ (unpublished data); $40 \%$ is considered the maximum bearing capacity of almond (Kester and Griggs, 1959). These data suggest that almost all visits by $O$ cornuta females crosspollinate almond flowers.

An average almond tree in a commercial orchard in NE Spain bears about 12000 flowers (Romero, personal communication). According to our results, 30 cornuta females would make a minimum of 28500 visits, which means that each flower would receive, on average, a minimum of 2.37 visits. Given the high pollinating efficiency of $O$ cornuta females, this seems to be more than enough to secure adequate pollination.

$O$ cornuta is a close relative to $O$ cornifrons and $O$ lignaria propinqua, which have been developed as orchard pollinators in Japan and the US, respectively (Maeta and Kitamura, 1974; Torchio, 1993). The number of recommended females per tree is 2.5-3 (Maeta and Kitamura, 1974, 1981) for $O$ cornifrons on apple (Yamada et al [1971] give values of 3-11), and 3 for $O$ lignaria propinqua on almond (Torchio, 1991).

Finally, the pollinating potential of male $O$ cornuta should not be neglected. Males 
do not live as long as females and they surely visit fewer flowers, but they are more numerous than females, and although their pollinating efficacy has not been directly measured, they always land on the reproductive organs of almond flowers, and are, therefore, likely to be good pollinators.

\section{ACKNOWLEDGMENTS}

I am grateful to $\mathrm{J}$ Calzadilla and MA Escolano for their assistance in field work, and to $M$ López for her assistance with laboratory work. I thank $J$ Retana (CREAF) for reviewing an early draft of the manuscript. This study was supported by an FPI grant of the Spanish Ministerio de Educación y Ciencia, and by funds of the INIA (project no 8191).

\section{Résumé - Comportement de nidifica-} tion de l'abeille maçonne Osmia cornuta (Latr) en rapport avec son efficacité pollinisatrice (Hymenoptera, Megachilidae). On a étudié le comportement de nidification d'Osmia cornuta sur des populations introduites dans des vergers d'amandiers. Le temps passé par les femelles à l'intérieur et à l'extérieur du nid a été mesuré. Les parois en boue des cellules et les charges de boue transportées par les abeilles ont été rassemblées et pesées. Les voyages des femelles pour récolter la boue duraient en moyenne 2,72 min et le déchargement 1,87 min (tableau 1). Le nombre de voyages nécessaires pour construire une paroi en boue était de 6,88 pour les premières parois, de 4,41 pour les parois intermédiaires, de 11,88 pour les parois du vestibule et de 21,09 pour les bouchons terminaux (tableau II). Les voyages de récolte de nectar et de pollen duraient en moyenne 11,48 min et le dépôt du nectar et du pollen 2,28 min. La ponte durait 4,11 min (tableau I). Les provisions de nectar et de pollen ont été séchées, pesées et mises en suspension dans l'eau. Des échantillons de ces suspensions de pollen ont été prélevés et les grains de pollen ont été dénombrés. On a pu ainsi établir une corrélation entre le nombre de grains de pollen et le poids sec d'une charge (fig 1). Les provisions dans les cellules de mâles et les cellules de femelles contenaient en moyenne 4364304 et 8046425 grains de pollen d'amandier, respectivement. Pour certains nids on a compté le nombre de voyages d'approvisionnement. En pesant les provisions formées, on a pu établir une corrélation entre le poids sec d'une provision et le nombre de voyages de butinage (fig 2). Le nombre moyen de voyages de butinage nécessaire pour faire une provision était de 16,76 pour les provisons des cellules de mâles et de 26,79 pour celles des cellules de femelles. La combinaison de ces résultats avec les données portant sur le nombre de fleurs visitées par unité de temps et sur la production des cellules donne une estimation du nombre de fleurs d'amandier visitées par une femelle d' $O$ cornuta qui nidifie dans un verger d'amandiers: il varie entre 9500 (dans des conditions météorologiques défavorables et des périodes de butinage courtes) et 23600 (lorsque le temps est favorable et la floraison prolongée). Étant donné l'efficacité pollinisatrice d'O cornuta, on considère que 3 femelles par arbre est un nombre suffisant pour assurer une pollinisation maximale d'un verger d'amandiers.

Osmia cornuta / nidification / pollinisation / Prunus amygdalus

\footnotetext{
Zusammenfassung - Das Nistverhalten der Mauerbiene Osmia cornuta Latr (Hymenoptera, Megachilidae) mit besonderer Berücksichtigung ihrer Bedeutung für die Bestäubung. Das Nistverhalten von Osmia cornuta wurde in künstlich
} 
gehaltenen Populationen im Bereich von Mandelkulturen studiert. Es wurden die Zeiten gemessen, welche die Weibchen inner- und außerhalb des Nestes verbrachten. Die Zellwände aus Erde und die von den Bienen transportierten Erdladungen wurden gesammelt und gewogen. Die Weibchen verbrachten im Durchschnitt 2,72 min auf einem Ausflug zum Sammeln von Nistmaterial, und 1,87 min zur Anbringung des Materials (Tabelle I). Die Zahl der Ausflüge zum Sammeln von Nistmaterial betrug für Zellwände am Beginn des Nestes 6,88, für Zwischenwände 4,41, für Vorraum-Wände 11.88 und für den $A b-$ schluß-Pfropf 21,09 (Tabelle II). Ausflüge zum Sammeln von Pollen und Nektar dauerten im Durchschmitt 11,48 min, das Ablagern von Pollen und Nektar 2,28 min, das Ablegen von Eiern 4,11 min (Tabelle I).

Der Pollen-Nektarvorrat der Zellen wurde getrocknet, gewogen und in Wasser suspendiert. Dann wurden Proben von diesen Pollensuspensionen entnommen, um die Pollenkörner zu zählen. Auf diese Weise konnte eine Korrelation zwischen der Pollenzahl und dem Trockengewicht gewonnen werden (Abb 1). Die Vorräte in männlichen und weiblichen Zellen enthalten im Mittel 4.634,304, bzw 8.046,426 Mandelpollenkörner.

In einigen Nestern wurde die Zahl der Sammelausflüge gezählt. Durch Feststellung des Trockengewichts der Vorräte wurde eine Korrelation zu der Zahl der Ausflüge hergestellt (Abb 2). Die mittlere Zahl der Sammelflüge betrug für die Vorräte/Zelle in männlichen Zellen 16,76 und für weibliche Zellen 26,79. Eine Kombination dieser Zahlen mit den Daten über die Zahl der Blütenbesuche pro Zeiteinheit und die Produktion von Zellen ermöglichte und die Schätzung, daß ein Weibchen von $O$ cornuta in einer Mandelanlage zwischen 9,500 (bei ungünstiger Witterung mit beschränkter Flugzeit) bis 23,600 (bei günstigen Wetter und langer Blühzeit) Mandel- blüten besucht. Berücksichtigt man die Leistungsfähigkeit von $O$ cornuta bei der Bestäubung der Mandel, so kommt man zu dem Schluß, daß drei Weibchen pro Baum zur optimalen Bestäubung in einer Mandelpflanzung ausreichen.

\section{Osmia cornuta / Nistverhalten / Bestäub- ung / Prunus amygdalus}

\section{REFERENCES}

Asensio E (1984) Osmia (Osmia) cornuta Latr pollinisateur potentiel des arbres fruitiers en Espagne (Hymenoptera, Megachilidae). Ve Symp Int sur la Pollinisation, Versailles, INRA, 461-465

Bosch J (1992) Osmia cornuta (Latr) (Hymenoptera, Megachilidae) como polinizador potencial de almendros. Ph D Thesis, University of Barcelona. $177 \mathrm{p}$

Bosch J (1994a) Osmia cornuta (Latr) (Hymenoptera, Megachilidae) as a potential pollinator in almond orchards: releasing methods and nest-hole length. J Appl Entomol 115 (in press)

Bosch J (1994b) Comparison of nesting materials for the orchard pollinator Osmia cornuta (Latr) (Hymenoptera, Megachilidae). Entomol Gen 19 (in press)

Bosch J (1994c) Improvement of field management of Osmia cornuta (Latr) for almond pollination (Hymenoptera, Megachilidae). Apidologie 25 (1), 62-74

Bosch J, Blas M (1994) Foraging behaviour and pollinating efficiency of Osmia cornuta (Latr) and Apis mellifera $L$ on almond (Hymenoptera, Megachilidae and Apidae). Appl Entomol Zool 29 (in press)

Fisher RA (1930) The Genetical Theory of Natural Selection. Clarendon Press. Oxford

Kester DE, Griggs WH (1959) Fruit setting in the almond: the effect of cross-pollinating various percentages of flowers. Proc Am Soc For Hort Sci 206-213

Kromblein KV (1967) Trap-nesting Wasps and Bees. Life Histories, Nests and Associates. Smithsonian Press. Washington, DC 570 pp 
Krunic MD, Jankovic D, Stanisic T (1989) Osmia cornuta Latr (Hymenoptera, Megachilidae) - Potential orchard pollinator. Arh Biol Nauka 41, 33-37

Krunic MD, Brajkovic MM, Mihajlovic LS (1991) Management and utilization of Osmia cornuta Latr for orchard pollination in Yugoslavia. Sixth Int Symp on Pollination. Acta Hortic 288, 190-193

Levin MD (1966) Biological notes on Osmia lignaria and Osmia californica (Hymenoptera: Apoidea, Megachilidae). I Kans Entomol Soc 3, 524-535

Maeta $Y$ (1978) Comparative studies on the biology of the bees of the genus Osmia in Japan, with special reference to their management for pollination of crops (Hymenoptera, Megachilidae). Bull Tohoku Nat Agric Exp Stn \# 57, $221 \mathrm{pp}$

Maeta Y, Kitamura T (1974) How to manage the Mame-Ko bee (Osmia cornifrons, Radoszkowski) for pollination of fruit crops. Ask Co Ltd $16 \mathrm{pp}$

Maeta $Y$, Kitamura T (1981) Pollinating efficiency by Osmia cornifrons (Radoszkowski) in relation to required number of nesting bees for economic fruit production. Honey-bee Science 2, 65-72 (in Japanese)

Márquez J, Bosch J, Vicens N (1994) Pollens collected by wild and managed populations of the potential orchard pollinator Osmia cornuta (Latr) (Hymenoptera, Megachilidae). J Appl Entomol 115 (in press)

Phillips JK, Klostermeyer EC (1978) Nesting behavior of Osmia lignaria propinqua Cresson (Hymenoptera, Megachilidae). J Kans Entomol Soc 51, 91-108

Taséi JN (1973a) Observations sur le développement d'Osmia cornuta Latr et Osmia rufa $L$ (Hymenoptera, Megachilidae). Apidologie 4, 295-315

Taséi JN (1973b) Le comportement de nidification chez Osmia (Osmia) cornuta Latr et $\mathrm{Os}^{-}$ mia (Osmia) rufa L (Hymenoptera, Megachilidae). Apidologie 4, 195-225
Torchio PF (1979) Use of Osmia lignaria Say as a pollinator of caged almond in California. Proc IVth Int Sympt on Pollination Md Agric Exp Sta Spec Misc Publ 1, 285-293

Torchio PF (1985) Field experiments with the pollinator species Osmia lignaria propinqua Cresson, in apple orchards: V, (1979-1980), methods of introducing bees, nesting success, seed counts, fruit yields (Hymenoptera, Megachilidae). J Kans Entomol Soc 58, 448-464

Torchio PF (1989) In-nest biologies and development of immature stages of three Osmia species (Hymenoptera, Megachilidae). Ann Entomol Soc Am 82, 599-615

Torchio PF (1991) Bees as crop pollinators and the role of solitary species in changing environments. Sixth int Symp on Pollination. Acta Hortic 288, 49-61

Torchio PF (1993) A case history in the development of Osmia lignaria propinqua as a managed pollinator of orchard crops. In: Experimental Studies in Pollination and Pollinator Foraging Efficiency (SL Buchmann, ed) (in press)

Torchio PF, Tepedino VJ (1980) Sex ratio, body size and seasonality in a solitary bee, Osmia lignaria propinqua Cresson (Hymenoptera, Megachilidae). Evolution 34, 993-1003

Torchio PF, Asensio E (1985) The introduction of the European bee, Osmia cornuta Latr, into the US as a potential pollinator of orchard crops, and a comparison of its manageability with Osmia lignaria propinqua Cresson (Hymenoptera, Megachilidae). J Kans Entomol Soc 58, 42-52

Torchio PF, Asensio E, Thorp RW (1987) Introduction of the European bee, Osmia cornuta, into California almond orchards (Hymenoptera, Megachilidae). Environ Entomol 16, 664667

Yamada M, Oyama N, Sekita N, Shirasaki S, Tsugawa C (1971) The ecology of the megachilid bee Osmia cornifrons and its utilization for apple pollination. Bull Aomori Apple Exp $\operatorname{Stn} 15,1-80$ 